This is an electronic reprint of the original article. This reprint may differ from the original in pagination and typographic detail.

Author(s): Ylönen, Sabine

Title: $\quad$ The position of Finnish and Swedish as well as other languages at universities in Finland

Year: $\quad 2015$

Version:

Please cite the original version:

Ylönen, S. (2015). The position of Finnish and Swedish as well as other languages at universities in Finland. In F. X. Vila, \& V. Bretxa (Eds.), Language Policy in Higher Education : The Case of Medium-Sized Languages (pp. 64-102). Multilingual Matters. Multilingual matters, 158. https://doi.org/10.21832/9781783092765-006

All material supplied via JYX is protected by copyright and other intellectual property rights, and duplication or sale of all or part of any of the repository collections is not permitted, except that material may be duplicated by you for your research use or educational purposes in electronic or print form. You must obtain permission for any other use. Electronic or print copies may not be offered, whether for sale or otherwise to anyone who is not an authorised user. 


\title{
4. The Position of Finnish and Swedish as well as Other Languages at Universities in Finland
}

\author{
Sabine Ylönen \\ University of Jyväskylä
}

\section{Introduction}

Finland has two national languages: Finnish and Swedish, and language policy is regulated by the Finnish Constitution (731/1999) and the Language Act (423/2003). About $90 \%$ of the population speaks Finnish and 5\% Swedish as their mother tongue. The Swedish-speaking minority lives mainly in the areas around the south-west coast of Finland. Over $90 \%$ of native speakers of Swedish live in the autonomous province of Åland, a group of islands in the Baltic Sea between Finland and Sweden, where the only official language is Swedish. There are four other minority languages Sami, Romani, Finnish sign language, and the Karelian language - but Statistics Finland databases only give information on the number of speakers for Sami. At $0.04 \%$ of the population, their number is very low despite the relatively large size of the area in the north of Finland where Sami speakers live. In 2012, about $5 \%$ of the population had mother tongues other than the three mentioned above, and only 3.6\% were foreign citizens (Statistics Finland, 2013: 5, 7).

Given the bilingual situation there is a fairly explicit regulation of language policy in Finland. In addition to the Finnish Constitution (731/1999) and the Language Act (423/2003), several other acts and decrees regulate language practices in specific societal domains. These include the Government Decree on Demonstrating Proficiency in Finnish and Swedish in the Public Administration (481/2003), the Universities Act (558/2009), and the Government Decree for Universities (770/2009). These legislative regulations deal mainly with the position of the national languages, Finnish and Swedish. Moreover the new government strategy for the national languages of Finland (Prime Minister's Office, 2012: 9) does not address on the position of foreign languages and their possible influence on language practices in Finland, particularly the influence of English in various societal domains such as science and education, except for an appeal to use Finnish and Swedish 'in all walks of life', including sciences, to maintain diverse vocabulary and expressions (p. 9). Otherwise the use of English is characterised as 'a natural development' 'in view of the international dimension of science'. This government strategy meets the aims of diversifying the national language resources and diversifying language programmes in basic education, postulated in the programme of Prime Minister Jyrki Katainen’s government (Prime Minister's Office, 2011: 51, 53), only with respect to the national languages. The autonomy of Finnish universities guarantees them freedom to regulate language practices independently, and the Finnish Ministry of Education (2008: 44) expects universities to develop language strategies. 
In the following sections, I will provide an overview of language policies and practices at Finnish universities. I will examine language policies at the governmental and university level, look at language practices in teaching and research, and consider discourses about languages in the Higher Education context in Finland. The section on language policy at university level will explore six questions related to language policy at Finnish universities. The first focuses on regulations governing language practices and the second on those concerned with language competences. The third and fourth questions deal with autonomy and differences between the language policies of different universities. The fifth is related to the fourth question, and is concerned with the role of academic disciplines in defining university policies. Finally, the answers to these five questions will be summarised by considering the question of whether Finland has a nation-wide university language policy. In the next section the focus shifts to language practices in instruction and research. Specifically, I will consider which languages are used by staff and students at universities in Finland in general. I will then go on to look at the language of instruction at different degree levels (undergraduate, master, doctorate and lifelong learning) and what practical language requirements teaching staff, students and administrative staff have to meet. I will also indicate which national and foreign languages they are expected to know, and discuss whether language competence is officially verified in any way. In this section on language practices, I will finally focus on language use for research (first, in scientific publications and second, in $\mathrm{PhD}$ dissertations). Finally, discourses about language policy at university level will be discussed followed by a brief summary and conclusions.

This chapter is based on a thorough analysis of a number of different types of texts, including Finnish legislative documents, documents of the Finnish Ministry of Education (and Culture), university documents, statistical data provided by the Centre for International Mobility (CIMO) and the National Statistics Centre of Finland, research publications and surveys as well as media news archives. The data on language use stems from two large surveys among students (about 3500 answers) and staff (about 3600 answers) of universities in Finland conducted in 2008 and 2009 within the FinGer project (German as a vehicular language in academic and business contexts in Finland, cf. Ylönen \& Vainio, 2010; Ylönen \& Kivelä, 2011). In addition, two extensive analyses were conducted for the purpose of this chapter: First, survey and archival research designed to explore the state and contents of university language policies, and second, a search through existing bibliographic sources to document the languages used for writing $\mathrm{PhD}$ dissertations from the 17th century to 2009. The study of university language policies was conducted in 2011 by contacting the rectors of 14 universities and two heads of the respective language policy working groups (there were 16 universities in Finland in 2011). In addition to analysing the language policy documents forwarded to me, information was gathered via e-mail correspondence and telephone interviews to explore the role of different academic areas in preparing language policies. The study of language choices for $\mathrm{PhD}$ dissertations was conducted in 2011 with the help of the register of all $\mathrm{PhD}$ dissertations in Finland purchased from the Finnish National Bibliography (FENNICA) database, which contained 45,592 titles. This data was analysed statistically using cross tabulation frequencies. The analyses carried out in 2011 were complemented with some new information during the editing of this paper in August 2013. 


\section{Language Policy at University Level}

\section{Are language practices regulated in an explicit way?}

University language practices are regulated explicitly by law because of the bilingual situation in Finland. In 2010, Finnish universities underwent reform when the number of universities was reduced from 21 to 17. In 2013, three more universities (the Finnish Academy of Fine Arts, the Sibelius Academy and the Theatre Academy, all located in Helsinki) merged to jointly establish the Arts University; consequently, Finland has 15 universities since the beginning of 2013. Fourteen of these are regulated by Finnish legislation, and these regulations also affect language practices (Universities Act, 2009). The fifteenth university is the Finnish National Defence University in Helsinki, which is not under civil jurisdiction because its administrative organisation is military rather than civilian. Northern Finland is very sparsely populated and there is only one university in Rovaniemi: the University of Lapland. Most of the 14 civilian universities are located in Southern Finland, and four of them are in Helsinki. There are ten multidisciplinary universities and four specialised universities. (see Appendix 4.1)

The languages of instruction and examination at Finnish universities are regulated by Section 11 of the Universities Act 558/2009. Nine universities are Finnish-medium universities, two are Swedishmedium, and three are bilingual Finnish-Swedish. In addition, two universities have separate units with special language regulations: the Swedish School of Social Science is attached to the University of Helsinki as a separate Swedish-language unit, and at the former Helsinki School of Economics (part of Aalto University since 2010), the language of instruction and examination is Finnish. The other two units that merged to form Aalto University - the University of Art and Design Helsinki and the Helsinki University of Technology - are Finnish-Swedish bilingual universities. This arrangement is based on the new Universities Act (558/2009, Section 11/1), under which the languages of instruction and examination at Aalto University are regulated by the provisions of its constituent schools, which are set out in section 9 of the Universities Act of 1997 (645/1997).

Seven universities have the responsibility to educate 'a sufficient number of persons proficient in Swedish for the needs of the country': the Åbo Akademi University, the Hanken School of Economics, the University of Helsinki, the Finnish Academy of Fine Arts, the Sibelius Academy, the Theatre Academy and Aalto University (Universities Act 558/2009, Section 12/1).

The language of university administration is regulated in Section 35 of the Universities Act 558/2009. Generally the administrative language at a university in Finland is Finnish. However, at two universities (Åbo Akademi University and the Hanken School of Economics), and at the Swedish School of Social Science of the University of Helsinki, the language of administration is Swedish. In addition, Section 35 regulates the right of everyone to use Finnish or Swedish and to receive documents in the language he or she uses: 'Everyone shall have the right to use Finnish or Swedish in matters concerning them and to obtain a document in the language he or she uses' (Universities Act 558/2009, Section 35/3). 


\section{Are language competences regulated in an explicit way?}

The reform of Finnish universities has also affected the legislative position of languages at the university level. The new Universities Act (558/2009) and the Government Decree (770/2009) came into force in January 2010. The main outcome of the reform was that Finnish universities are now independent legal bodies, and staff are no longer employed by the government. Because staff at Finnish universities are no longer considered civil servants, their employment contracts had to be renewed. Section 35 of the Universities Act provides that Finnish and Swedish language proficiency requirements for teaching and research staff and other personnel are established in the Government Decree. However, this Decree only contains regulations for teaching and research staff. In the first section (Government Decree 770/2009, Section 1) language competences are regulated as follows:

- University teaching and research staff are required to be proficient in the language - Finnish or Swedish - that they are supposed to use for instruction.

- Requirements with respect to proficiency in the language of instruction may be specified in university regulations.

- At universities where a degree may be taken in either Finnish or Swedish, teaching and research staff must have at least satisfactory oral and written proficiency in Finnish or Swedish.

— The university may grant exemptions from these language proficiency requirements as provided in university regulations.

Compared with the previous decree (463/1998), these regulations are less rigorous because teaching and research staff were formerly considered civil servants and competence in both Finnish and Swedish was required under the Act on the Language Skills of Civil Servants (149/1922; full proficiency in the majority language of the university as well as proficiency in understanding the second official language). This Act was replaced in 2003 by the Act on the Knowledge of Languages Required of Personnel in Public Bodies (424/2003), under which employees were required to have the language proficiency needed to perform their duties.

One exception is Åbo Akademi University, where the university defines its own policy and no separate decree regulates requirements for teaching and research staff. These regulations have not been radically changed compared to the previous Universities Act (645/1997). Section 78 of the new Universities Act 2009 contains the following provisions:

A requirement for a teaching position at Åbo Akademi shall be full proficiency in the Swedish language and an ability to understand the Finnish language. The decision on the proficiency in Swedish and Finnish required of a foreigner or a non-native Finnish citizen shall rest with Åbo Akademi. Åbo Akademi has a language board to which the proficiency in Swedish referred to in subsection 1 can be demonstrated. (Universities Act 558/2009, Section 78)

Because staff members are no longer civil servants, language competences for other university personnel are not as clearly regulated today as they were before the 2010 university reform. In this respect, the university reform was probably conducted too hastily, without considering the consequences in terms of the language requirements that apply to this group of 'other personnel'. It is now up to universities to define language requirements for recruitment purposes. 


\section{To what extent are universities autonomous in defining their language policy?}

As discussed above, universities today are more autonomous in defining their language policy than before the 2010 reform. This applies especially to the language competence of other personnel. As regards instruction and examination, universities have been free to use languages other than Finnish and/or Swedish for instruction and examination since 2004 (Universities Act 645/1997, Amendment 715/2004), and the new Universities Act does not differ much in this respect: 'In addition, the university may decide to use a language other than that referred to in Article 1 as a language of instruction and examination' (Universities Act 558/2009, Section 11/2).

In relation to the previous Universities Act 645/1997 and its Amendment 715/2004, the only new words introduced are 'in addition', which highlights the fact that the university has to ensure the role of the national languages, Finnish and Swedish, by emphasising that no foreign language may replace the language(s) of instruction and examination as regulated by the new Universities Act, Section 11 (see Appendix 4.1).

When recruiting new staff, universities regulate the language proficiency required for the performance of the duties associated with a position. Announcements of new vacancies generally contain case-specific requirements for teaching, research and other personnel. In most cases, English proficiency (speaking and understanding) is now specified as being either a requirement or an advantage to perform the duties associated with posts.

The Ministry of Education expected all universities to formulate their own language policies during 2009, and to include measures for demonstrating the language proficiency required to teach in a foreign language:

Higher education institutions will draw up language strategies covering their entire operations during 2009. Higher education institutions will require that teachers teaching in a foreign language demonstrate their skills in the teaching language with a language proficiency certificate or in another recognisable manner. (Ministry of Education, 2008: 44)

The extent to which such university language policies have been developed will be discussed in the next section.

\section{Do different universities have different language policies?}

Information on university language policies was difficult to obtain, because policy documents are often for internal use only. Some language policies were found on the public web pages of the universities. They had usually been prepared by working groups appointed by the rector of the university in question. To obtain further information, e-mails were sent to the rectors of 14 universities in October 2011. At two universities, the heads of the respective working groups were contacted directly. Our aims were to explore whether the universities had developed or were developing their own language policies, and to find out which academic areas were relevant to the process of defining them (see next question).

We received answers from 13 universities. At the end of 2011, seven of the sixteen universities had developed language policies, and one had developed a language policy for support and 
administrative services. One of the predecessors of the University of Eastern Finland (the University of Joensuu, which merged with the University of Kuopio in 2010) had already developed a language policy in 2006, and the new language policy for both units came into force in December 2011. At three more universities, language policies were being prepared to come into effect in 2012 at the earliest. The oldest language policy at any European university (adopted in 2004) - the one in place at the time of this study in 2011 at the University of Jyväskylä - was being updated at the time of the study. Table 4.1 shows the state of university language policies in Finland in January 2012 (upper part) supplemented with information gathered in August 2013 (lower part of the table).

Two universities responded that they were not planning to develop a university language policy and did not consider this an important issue. Three universities did not respond. It is assumed that they have no language policies and are not currently developing any. One reason may be that smaller universities in particular do not have the resources to focus on developing language strategies, because a lot of their energy is still going into implementation of the university reform. Also, another merger of three universities to establish the Arts University was planned at the time of this study.

To sum up, in January 2012 half of the universities had language policies in place (8/16), and three more universities announced they would have such policies available by the end of 2012 . Consequently, 69\% of Finnish universities (11/16) planned to have prepared a language policy by the end of 2012. The situation in 2013 at the time of revising this chapter, after another merger of three universities to establish the Arts University, is that 71 per cent of the universities (10/14, i. e. excluding the Theatre Academy) have formulated their language policy.

Table 4.1 Language policies at Finnish universities (in January 2012 and August 2013)

\begin{tabular}{|c|c|c|c|c|}
\hline & \begin{tabular}{|l|} 
Year of \\
approval
\end{tabular} & Name & $\begin{array}{l}\text { Document } \\
\text { language(s) }\end{array}$ & $\begin{array}{l}\text { Length } \\
\text { (pages) }\end{array}$ \\
\hline \multicolumn{5}{|c|}{ Results of the first study (January 2012) } \\
\hline \multirow[b]{2}{*}{ University of Jyväskylä } & 2004 & Language Policy & FI, EN & 9 \\
\hline & 2012 & $\begin{array}{l}\text { Kielipolitiikka (Language } \\
\text { Policy) }\end{array}$ & $\begin{array}{l}\text { FI (EN in } \\
\text { preparation) }\end{array}$ & 15 \\
\hline Hanken School of Economics & 2005 & Språkstrategi & SE & 6 \\
\hline University of Helsinki & 2007 & Language Policy & FI, SE, EN & $\begin{array}{l}61 \text { (about } \\
20 \text { per } \\
\text { language) }\end{array}$ \\
\hline Åbo Academy & 2009 & Language Policy Programme & SE, EN & 3 \\
\hline University of Vaasa & 2010 & $\begin{array}{l}\text { Kielilinjaukset (Language } \\
\text { Guidelines) }\end{array}$ & FI & 3 \\
\hline Aalto University & 2010 & Language Guidelines & FI, SE, EN & 3 \\
\hline \multirow{2}{*}{$\begin{array}{l}\text { University of Eastern Finland } \\
\text { (University of Joensuu) }\end{array}$} & 2011 & $\begin{array}{l}\text { Kielipoliittinen ohjelma } \\
\text { (Language Policy Programme) }\end{array}$ & $\begin{array}{l}\text { FI (to be } \\
\text { translated into } \\
\text { EN) }\end{array}$ & 20 \\
\hline & (2006) & $\begin{array}{l}\text { Kielistrategia (Language } \\
\text { Strategy) }\end{array}$ & FI & 34 \\
\hline $\begin{array}{l}\text { Theatre Academy (merged } \\
\text { with Sibelius Academy \& } \\
\text { Academy of Fine Arts to the } \\
\text { Arts University in 2013) }\end{array}$ & 2010 & $\begin{array}{l}\text { Tuki- ja hallintopalveluiden } \\
\text { kieli- ja käännösperiaatteet } \\
\text { (Language Policy for Support } \\
\text { and Administrative Services) }\end{array}$ & FI & 9 \\
\hline
\end{tabular}




\begin{tabular}{|l|l|l|l|l|}
\hline Results of the updated study (August 2013) \\
\hline University of Turku & 2012 & $\begin{array}{l}\text { Kieliohjelma (Language } \\
\text { Policy) }\end{array}$ & FI, EN & 14 \\
\hline $\begin{array}{l}\text { Tampere University of } \\
\text { Technology }\end{array}$ & 2012 & $\begin{array}{l}\text { Kielisuunnitelma (Language } \\
\text { Plan) }\end{array}$ & FI, EN & 9 \\
\hline University of Tampere & 2013 & $\begin{array}{l}\text { Kieliperiaatteet (Language } \\
\text { Strategy) }\end{array}$ & FI, EN & 4 \\
\hline
\end{tabular}

The language policy documents have different names at different universities and are available in one to three languages: Finnish, Swedish and English (FI, SE, EN); Finnish and English (FI, EN); Swedish and English (SE, EN); or a single language, either Finnish (FI) or Swedish (SE). They also differ in content and length.

As far as contents are concerned, the legislation and regulations on the national languages (Finnish and Swedish) were generally taken into account, and the policies emphasised internationalisation and the importance of English. All the university policies highlighted the importance of offering good opportunities for foreign personnel and students to learn the national languages, which was also seen as a way of supporting their integration into the university environment. On the other hand, providing English-language services was mentioned as a way of benefiting international recruitment. Some language policies were very explicit about specific measures for teaching, research, internal and external communication, and administration, whereas others were somewhat vague on this point. As regards the publication of research results, the dominant role of English was generally acknowledged, but publishing in the national languages was also seen as important in all the university language policies. There was scant reference to publishing in foreign languages other than English, and at some universities the tone on this point was one of 'tolerance' ('if strategically important'). In January 2012, only at the University of Helsinki was the importance of publishing in foreign languages other than English articulated on a more general level: 'The University also believes in the importance of publishing scientific and other scholarly work in foreign languages other than English' (University of Helsinki, 2007: 47).

Some universities referred to multilingualism and multiculturalism as resources within the academic environment and emphasised competence in foreign languages other than English, as for example in the case of the University of Helsinki and the University of Jyväskylä:

Multilingual and multicultural communities promote creative thinking. (University of Helsinki, 2007: 41)

Since English is not enough to meet the needs of foreign language competence for academically trained Finns, the University will make it possible for students to expand their foreign language skills in other languages. (University of Jyväskylä, 2004: 4)

However, the new language policy of the University of Jyväskylä (2012b) no longer mentions the need to expand foreign language skills into other languages. Instead, it more or less takes multilingualism for granted and emphasises the importance of 'partial language competences' (see also below). Also most other universities made only vague reference to the importance of 'multilingualism' and 'other foreign languages' without offering any further details. Aalto University (2010: 2), for example, states that it encourages 'linguistic diversity and parallel use of languages'. The concept of 'multilingualism' varied at different universities, from including only 
three languages (Finland's national languages - Finnish and Swedish - and English as the academic lingua franca) to also encompassing foreign languages other than English. Only at two universities were the languages of students, researchers and other staff with immigrant backgrounds referred to as important resources in the academic context.

Only the University of Helsinki explicitly pointed out the growing impact of English as a foreign language and the related risk of a weakening of users' skills in their first language and in languages other than English. In what is clearly a response to this point, the new language policy of the University of Jyväskylä (2012b: 1) defines 'modern multilingualism' as also comprising partial language competences and parallel use of languages in certain situations. On the one hand, this concept of 'modern multilingualism' is commendable because it might encourage people to use all the resources available to them in their language repertoires as the situation requires. On the other, on its own it does not help to identify strategically important languages other than English. Nor does it help to promote strong skills in these other languages (for example through measures to develop related possibilities for studying languages as major and minor subjects, or for specific academic and vocational purposes at the Language Centre). The 'operational programme' published in June 2012 at the University of Jyväskylä did not include any strategies for promoting foreign languages other than English.

Up until January 2012, only the documents of the universities of Helsinki and Eastern Finland explicitly named foreign languages other than English. The University of Helsinki, for example, listed as strategically important academic languages 'German, French, Spanish, Russian and Chinese, among others'. These were seen as supporting global development and European integration and 'required within academia and in Finnish society at large' (University of Helsinki, 2007: 45). The language policy of the University of Eastern Finland singles out Russian as having a special status within the university's strategy. Apart from Russian, only English was mentioned as strategically important in connection with major subjects ('English and Russian, among others'). This vague expression 'among others' obviously offers the possibility of giving up other languages as major subjects. The possibility of reducing the number of universities that offer certain languages as major subjects is currently under discussion in connection with the university reform. The University of Eastern Finland listed Chinese, English, Finnish for written and spoken communication, Finnish as a second language, French, German, Spanish, Swedish and Russian as languages offered by its Language Centre. In addition, degrees in French, German, and Russian as a minor subject are to be offered by the Language Centre via a new channel (University of Eastern Finland, 2011: 7, 12).

At some universities, there was a special focus on developing communication in Swedish and English to promote internationalisation of the home university and expand academic cooperation with Nordic countries and globally. Here, other foreign languages were not mentioned at all.

An additional analysis of the three language policies published in 2012-2013 (after this first study) showed interesting developments towards a more concrete definition of language policy objectives and measures. All three universities are Finnish-medium, and the role of Finnish for teaching, publication of research results for the local society, and university services is acknowledged. In addition, the role of English in university communication is highlighted in all of these new language 
strategies. However, there are interesting differences in valuing languages other than English and Finnish between the Universities of Turku and Tampere on the one hand and the Tampere University of Technology on the other.

The language policy of the University of Turku, completed in 2012 describes its approach as being based on the principle of 'parallel lingualism [...] because many other languages are also required in the international academic community, the aim is to teach and use them whenever possible'. All students, except for international students, are expected to have good oral and written proficiency in Finnish. For academic cooperation, the Baltic Sea region (Scandinavian languages, German, Estonian and Russian), the European academic and cultural community (French, Spanish and Italian), and Asian languages (Chinese and Japanese) are mentioned as being specifically important. Also languages offered as a major subject are stated: Finnish, English, Spanish, Italian, Scandinavian languages, French, German and Russian of the modern Indo-European languages, and Greek and Latin of the classical languages. Likewise, the language strategy of the University of Tampere, completed in March 2013, highlights the importance of foreign languages other than English for international collaboration as well as in teaching and publishing research without naming any foreign languages specifically. On the contrary, the new Tampere University of Technology language plan adopted in 2012 aims primarily to strengthen and support English 'as a medium of instruction and above all as a language of science'. For example, master's level studies are planned in English by 2020, and the publication of 'important scientific articles will be published on international forums primarily in English'. Also for recruiting new support staff the candidates’ proficiency in English will be one of the recruiting criteria.

In sum, whereas the Universities of Tampere and Turku espouse wider use of different languages, the Tampere University of Technology sees English as the first and foremost important language in teaching and research to become an internationally active and recognised university.

In the next section, the role of different academic disciplines in formulating university language policies will be briefly discussed.

\section{Are academic areas (natural sciences, humanities, etc.) relevant to defining university}

\section{language policies?}

One aim of this study was to look at which academic and occupational areas were involved in defining university language policies. Appendix 4.2 shows the number of participants in the development of university language policies and their working areas.

On average, the groups preparing university language policies consisted of nine members (4-14). Representatives of those concerned with language as an object of study (from language departments and/or Language Centres), university administration (international relations, public relations and the university's central administration), and students were usually involved in the process. Representatives from other academic fields (natural and technical sciences, business, social sciences and philosophy, theology and the humanities) also participated to varying degrees. Some universities at least had their draft documents reviewed by all faculties to get feedback. Overall, different academic fields were quite well represented. Nevertheless, the documents themselves were written on a rather general level and did not go into detail for different disciplines. Instead, 
responsibility for concrete guidelines on discipline-specific communicative conventions was passed on to departments or units.

\section{Can we speak of a nation-wide university language policy?}

As shown in the previous sections, the answer to the question of whether Finland has a nation-wide university language policy is both 'yes and no'. 'Yes' is the answer with respect to the national languages, Finnish and Swedish, which are regulated by law as languages of administration, instruction and examination. 'No' is the answer for foreign languages, because by law universities are guaranteed freedom of choice to decide on the use of languages other than Finnish or Swedish for instruction and examination.

Universities make use of this 'freedom of choice', but English is practically the only language other than Finnish or Swedish that is chosen as a language of instruction and examination, and for administrative use. Other foreign languages were sometimes mentioned in a rather vague manner in the context of exchange programmes or research, and more specific strategies for foreign languages other than English were found only at three universities (Universities of Helsinki, Eastern Finland and Turku). Responsibility for more specific language policies was delegated to departments. One thing evident from this study is that the universities clearly did not cooperate in developing their language policies, even though some of the documents contained references to the policies of other universities. Common topics were internationalisation and the importance of English. Attention was also given to legislative regulations concerning the national languages, Finnish and Swedish.

\section{Language Practices at University Level}

\section{Which languages are used by students and staff of universities in Finland?}

A comparison of two large surveys among students and staff at Finnish universities showed that English has become practically the 'second national language' in academic life (see Figure 4.1). It is used almost to the same extent as Finnish and more than Swedish (one of the official national languages) when considering any language use. Altogether, we received 3513 valid answers from students in 2008 and 3598 from staff members in 2009 (Ylönen \& Kivelä 2011, Ylönen \& Vainio 2010). Responses to the question 'any language use' were recorded with a frequency ranging from 'daily' to 'seldom' on the staff survey, and in the range from 'mostly' to 'seldom' on the students survey. Responses were given on a five-point Likert scale, with the fifth value corresponding to 'not at all', here combined with no answer. In Figure 4.1, any language use (daily/mostly-seldom) is summarised. However, more detailed analyses of the frequencies showed that in the staff groups, the 'daily use' figures were $90.7 \%$ for Finnish, $65.5 \%$ for English, and $13.1 \%$ for Swedish (see Ylönen \& Kivelä 2011: 42). In the student group, 86.6\% indicated they used Finnishmostly, 36.5\% used English mostly, and 3.3\% Swedish mostly (see Ylönen \& Vainio 2010: 37).

Whereas Finnish and English were used to about the same extent across professional groups and among students, the use of other languages varied slightly more (again for 'any use'). Professors and managerial staff used languages other than Finnish and English to a greater degree than other groups of personnel. This suggests that versatile language skills enhance career potential at universities. 


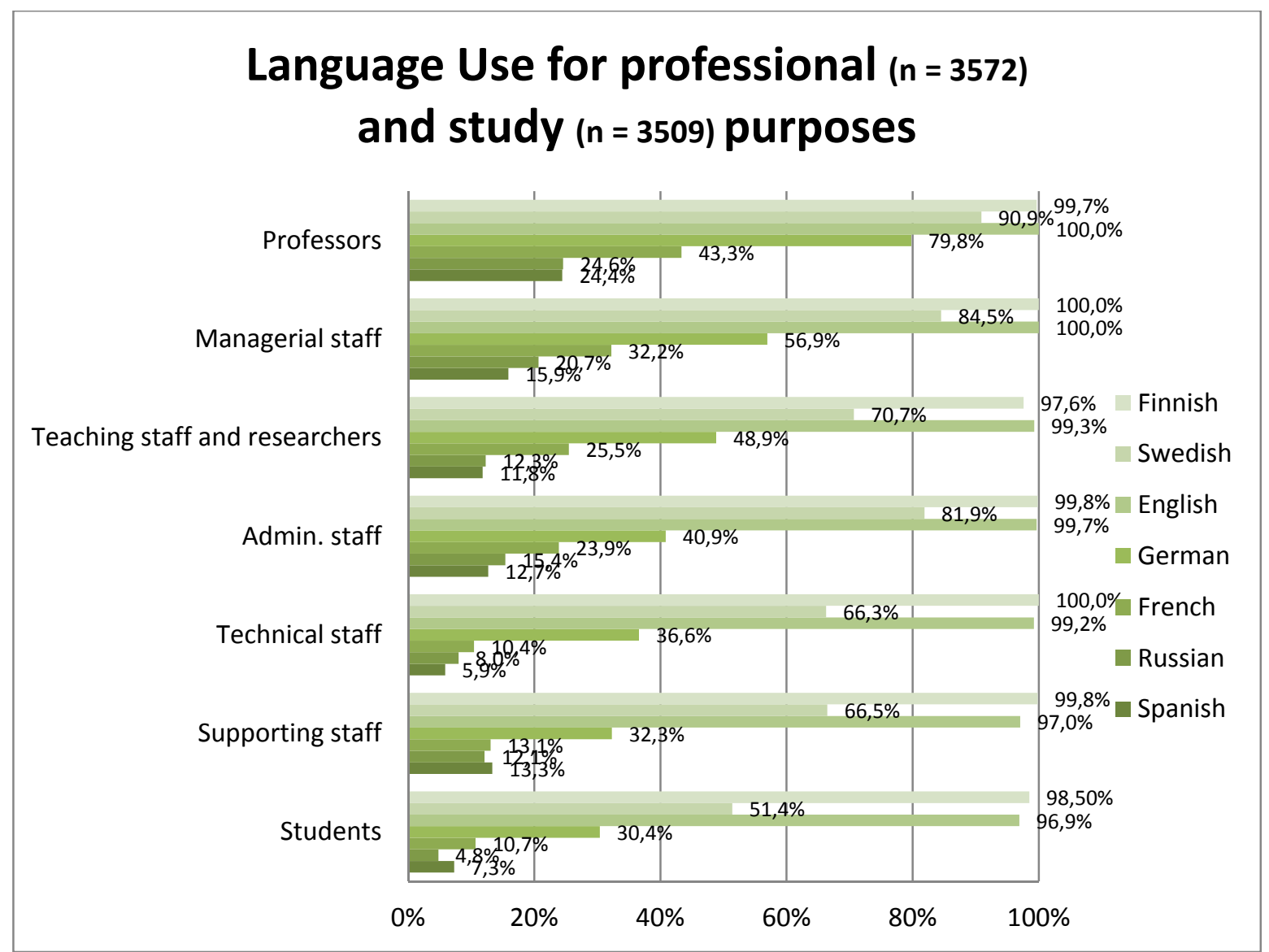

Figure 4.1 Comparison of any language use (daily/mostly-seldom) between different personnel groups (Which languages do you use at work and how often?) and students (Which languages do you use in your studies in Finland except compulsory language and communication studies?)

Among university students, languages other than Finnish and English were used to a lesser degree than in any of the staff groups (except for the technical staff group). Due to the dominant role of English, the motivation to learn and use other foreign languages is clearly lower in the younger age groups. A comparison of age groups showed a clear tendency towards fewer language skills and more limited use among younger age groups of university staff (Ylönen \& Kivelä, 2011: 47-50).

In the survey among university staff (Ylönen \& Kivelä, 2011), the proportional language use for reading, writing, listening, speaking, and other use was also explored. The question we posed was: 'For which purposes do you use the following languages as working languages?' Respondents could select all the answers that were applicable. Considering any use (daily/mostly-seldom), the results showed that Finnish was mostly used for speaking (95\%), whereas English was mostly used for reading in academic contexts (96\%; see Figure 4.2). 


\section{Purposes of working languages}

$$
(n=3582)
$$

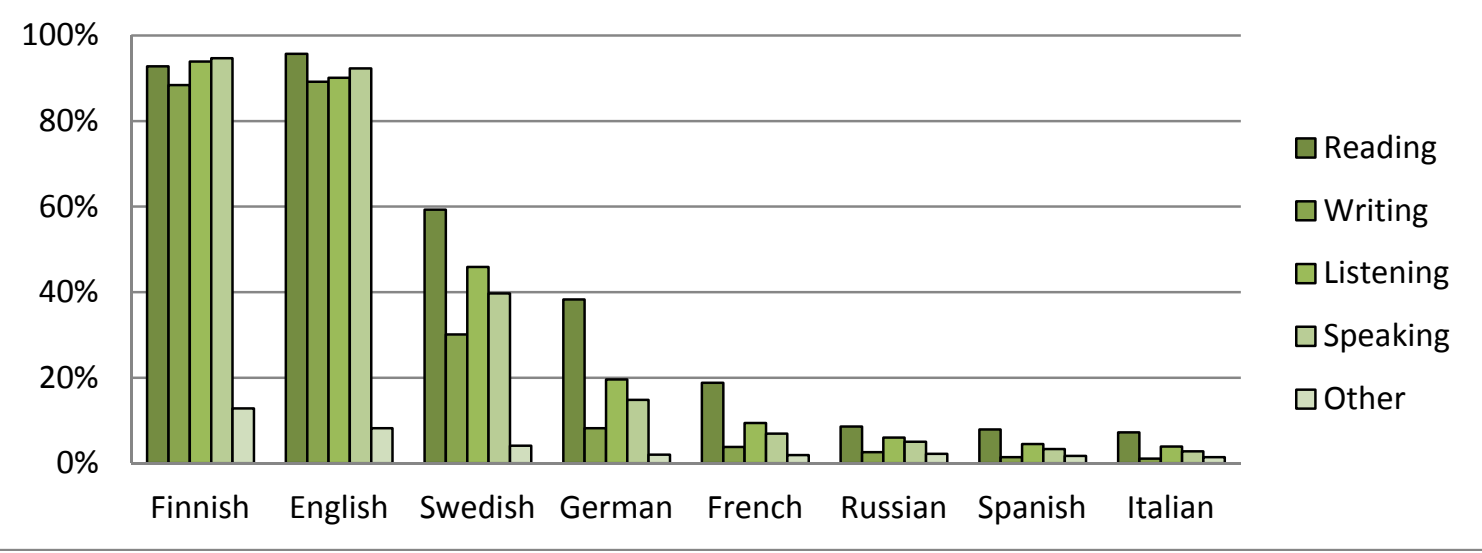

Figure 4.2 Language use at Finnish universities in terms of different skills. Source: Ylönen \& Kivelä (2011: 43)

Overall, both Finnish and English were used more or less equally ( $\pm 90 \%)$ for reading, writing, listening and speaking purposes. However, Finnish was the language used most for speaking, and English was used most for reading. Bigger differences in these four core components of language use could be observed for the other languages. In these cases, reading was clearly the commonest use and writing was the least frequent. The differences between listening to and speaking languages other than Finnish and English were not as marked. 'Other' - generally less frequently mentioned activities - were, for example, thinking, singing or using some form of sign language. Overall, university staff claimed that they used Swedish less than Finnish and English for oral purposes (46\% for listening and 40\% for speaking). As for foreign languages other than English, only German and French were mentioned as being used to a higher degree at least sometimes for oral academic purposes (German about 20\% for listening and 15\% for speaking, and French 9\% for listening and $7 \%$ for speaking), whereas other languages received only values below $5 \%$. These figures show that Finns are indeed still very plurilingual and obviously value multilingualism highly, which is also reflected in the answers given for a separate question: 'How important are different languages in a university working environment in your opinion?' A large majority of respondents (92.8\%) indicated that they regard multilingualism as very important or important (see Ylönen \& Kivelä 2011: 39). Nevertheless, without a higher education policy that addresses the role of languages more directly and develops appropriate support measures, the future may look quite different.

\section{Which languages are used for instruction at different degree levels?}

The constitution of Finland guarantees everyone the right to use his or her own language, either Finnish or Swedish, in dealings with authorities, and to receive official documents in that language. On the other hand, offering degree programmes in 'foreign languages' has become one of the strategic focuses in Finnish higher education. 
Undergraduate-level teaching is conducted mostly in Finnish or Swedish, but there are attempts to increase teaching in 'foreign languages', because international degree programmes have become central to the development of internationalisation in Finnish higher education since the start of this century (Garam, 2009: 2). Consequently, departments are expected to offer more undergraduatelevel teaching and MA programmes in 'foreign languages', a direction supported by university councils or senates. Undergraduate-level teaching and MA programmes are therefore also targets of strategic financing.

Nevertheless, despite high percentages of international degree programmes taught in English, the proportion of foreign students is relatively low when compared internationally (see Table 4.2, Table 4.3 and Figure 4.3). According to Wächter and Maiworm's (2008: 25-26) large-scale surveys, in 2007 Finland had the highest number of institutions (66\%) offering English-taught bachelor's and master's programmes among 27 European countries, followed by Cyprus (50\%) and the Netherlands (42\%). In 2008 there were 275 degree programmes taught in English (see Table 4.2). Among these degree programmes taught in English at the bachelor's, master's and doctoral levels, most were offered in the field of business (23\%), engineering and technology (20\%), and information technology (12\%) (Garam, 2009: 13). However, there are university-specific differences. At the University of Jyväskylä, for example, the School of Business and Economics ranks first in foreign language teaching, which accounts for $24.7 \%$ of all credit points awarded at the bachelor's and master's levels (there are no official doctoral level programmes taught in English at the University of Jyväskylä), followed by the Faculty of Sports (9.6\%), and the Faculty of Arts and Humanities (8\%).

Table 4.2 Degree programmes in Finland taught in English by educational level for 2008

\begin{tabular}{|l|l|l|l|l|}
\hline & UAS & Uni. & Total & Total\% \\
\hline Bachelor & 79 & 4 & 83 & 30 \\
\hline Master & 15 & 156 & 171 & 62 \\
\hline Doctorate & - & 21 & 21 & 8 \\
\hline Total & 94 & 181 & 275 & 100 \\
\hline
\end{tabular}

Source: Garam (2009: 13). UAS = universities of applied sciences, Uni. = universities

However, compared to the figures given in Table 4.2, Brenn-White and van Rest (2012: 8) list a divergent number for English-taught master's programmes in Finland at MastersPortal, and Välimaa et al. (2013: 20-21) point to the fact that probably nobody knows the exact number of international degree programmes in Finland or in Europe due to the lack of reliable records running at a given time. They state that the only reliable indication is that the number of programmes taught in English is growing continuously. This tendency is confirmed and vividly illustrated by the updated report of the Institute of International Education (Brenn-White \& van Rest, 2013: 4).

The number of foreign degree-level students in Finnish higher education institutions has also grown steadily, reaching about 5\% of all students in 2010. This means that the number has practically doubled since the beginning of this century (see also Garam \& Korkala, 2011: 34-35). The increase has taken place slightly faster at universities of applied sciences (5.7\% in 2010) than at universities (4.6\% in 2010) (see Figure 4.3). 


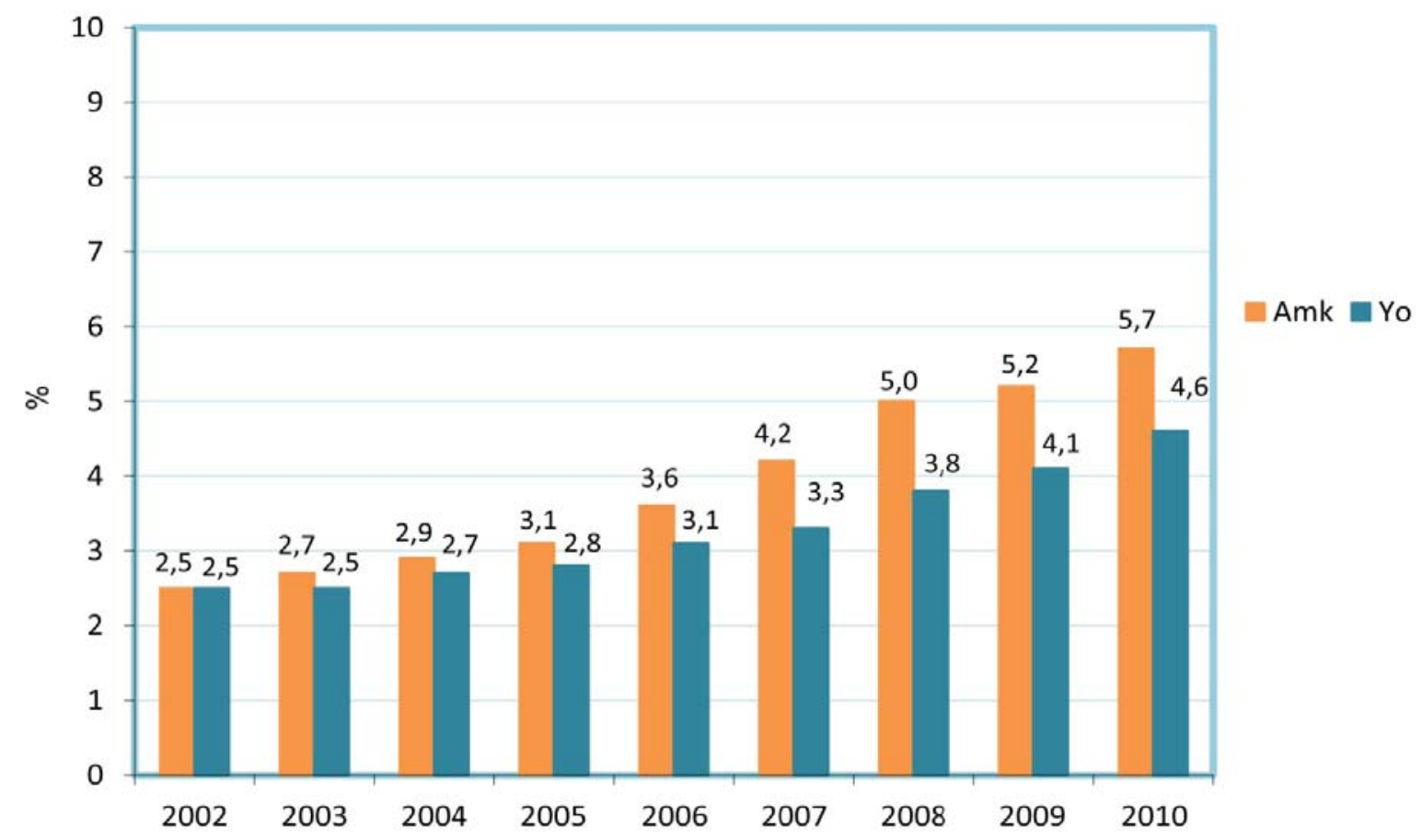

Figure 4.3 Foreign degree students in relation to the total number of students at Finnish Universities (Yo) and Universities of Applied Sciences (Amk). Source: Cimo 2011 (based on Statistics Finland, KOTA and AMKOTA databases)

A more detailed analysis of the data in the KOTA database showed that the number of international doctoral and master's degree students at Finnish universities increased from 2007 to 2009, while the number of foreign bachelor's degree students decreased slightly over the same period (see Table 4.3).

Table 4.3 Percentage of foreign degree students at Finnish universities 2007-2009.

\begin{tabular}{|l|l|l|l|}
\hline & $\mathbf{2 0 0 7}$ & $\mathbf{2 0 0 8}$ & $\mathbf{2 0 0 9}$ \\
\hline Bachelor & $1.3 \%$ & $1.1 \%$ & $1.0 \%$ \\
\hline Master's & $3.5 \%$ & $6.9 \%$ & $7.8 \%$ \\
\hline Doctorate & $8.5 \%$ & $9.3 \%$ & $10.5 \%$ \\
\hline Other & $3.3 \%$ & $3.8 \%$ & $3.8 \%$ \\
\hline Total & $3.3 \%$ & $3.8 \%$ & $4.1 \%$ \\
\hline
\end{tabular}

Source: KOTA database

At less than 4\% of all higher education students in 2008, the number of foreign students has been below the OECD average of 6.9\% (Garam, 2009: 13). In its 2009-2015 internationalisation strategy for higher education institutions, the Finnish Ministry of Education has set the target of increasing the number of foreign degree students considerably by 2015 (from 11,303 =3.7\% in 2007 to 20,000 $=7 \%$ in 2015). These figures include both first-degree and postgraduate students in all higher education institutions. The international student population (and international personnel) is seen as 'a key factor in Finnish higher education institutions' internationalisation at home' (Ministry of Education, 2009a: 10, 29, 30). 
The Research and Innovation Council of Finland (RIC) concluded in 2009 that 'Finnish higher education institutions have not gained a foothold in the rapidly growing global education market' despite the high number of degree programmes taught in 'a foreign language' (RIC, 2009: 17) Although their tuition fees are high, English-speaking countries (especially Australia, the United Kingdom and the United States) have traditionally attracted the majority of Asian students who study abroad (Hughes, 2008). In Finland, where higher education has been free for everyone, the 2010 university reform led to the launch of a trial project that enables universities and polytechnics (now called 'universities of applied sciences') to collect fees from foreign students from outside the EU/EEA area who participate in foreign-language master's programmes. A prerequisite for participating in this tuition fee trial is the university grant system, and the trial will be evaluated in 2012 (Ministry of Education and Culture, 2011a: 14). Nine universities and ten polytechnics are taking part in the trial, which started in 2010 and will run to 2014, and a total of 130 degree programmes are involved. The participating higher education institutions are free to decide the amount of the tuition fee. In 2010, half of the trial programmes collected such fees; others intend to start applying them later in the trial period (new programmes may also join the trial). During the trial period, the effects of introducing tuition fees on the internationalisation of universities, the attractiveness of higher education in Finland, student flows, and the quality of higher education in a foreign language will be evaluated (Ministry of Education and Culture, 2011a: 20).

As for lifelong learning, no language policy is specified by the Ministry of Education (2009b) in its latest interim report 'Key competences for lifelong learning in Finland'. There are also no registers for continuous education in Finland. However, universities do offer training for their staff in English. At the University of Jyväskylä, for example, four institutions offer staff training in English on a regular basis. These are 1) the Information Management Centre (partly in cooperation with the University Library), 2) the Research and Innovation Office, 3) the International Office, and 4) the Language Centre. In 2011, for example, there were courses on the use of computer management systems (CBS: Optima) and on the study register (Korppi), organised by the Information Management Centre. Training on the use of the JyU dissertation template and RefWorks reference manager was also offered in cooperation with the University Library (four courses). The Research and Innovation Office has also offered four courses in English (out of a total of 17), which means that about one fifth (23.5\%) of the staff training offered by the office was in English. In addition, annual information events for foreign staff are organised by the International Office. The Language Centre offers courses in Finnish as a foreign language and staff training in English (for example, TACE - Teaching Academic Content through English, Fundamentals in Intercultural and Multilingual Communication, and 'What Can I Do for You? - Asiakaspalveluenglantia' Customer Service English). There are no overall statistics concerning [foreign] languages used in staff training, but the officer responsible estimates that it amounts to about $5 \%$ of all staff training organised by the university.

Although strategy documents usually refer to 'foreign languages', in practice all degree programmes in Finnish higher education are taught in English and none are offered in any other non-native language (Garam, 2009: 14). Saarinen (2012: 237) points out that language is rarely mentioned and becomes almost invisible when observed at the micro level of foreign language programmes. She concludes that language is clearly regarded as something so self-evident that it need not be problematised. In my view, the euphemism 'foreign language' may also be motivated 
by a widespread appreciation of multilingualism among academically trained Finns, who have traditionally been plurilingual (see Ylönen \& Kivelä, 2011). Also Saarinen suggests that the use of 'foreign language' may be related to the Finnish goal of promoting other languages as well (Saarinen, 2012: 243). However, given that the use of languages in the academic context is also linked to power relations, strategic measures are needed if future generations are also to value foreign languages other than English.

To sum up, internationalisation strategies have led to English being favoured without any reflection on the role of language in cognitive and socio-cultural aspects of education and research. According to a survey conducted by the Finnish Centre for International Mobility (CIMO), many degree programmes taught in 'a foreign language' (i.e. English) are motivated by the goals set in national and institutional internationalisation strategies. The results of this study also showed that a third of these programmes had not defined their target group (Finnish students, international students or immigrant Finns), and many were vague about the labour markets and target countries for which they were educating students (Garam, 2009: 6, 9). On the whole, the role of language(s) in education and research should be more thoroughly examined. One could also ask whether English is the only key to internationalisation, which facets of this phenomenon could and should be taken into account and supported, and why and how this could be done.

\section{What are the practical language requirements that teaching staff, students and administrative staff have to face?}

\section{Teaching staff}

As indicated above, teaching staff are expected to master the language of instruction (Finnish or Swedish). At bilingual universities, satisfactory oral and written proficiency in Finnish and Swedish is required. Exemptions may be granted based on university regulations (Government Decree $770 / 2009$, Section 1). When teaching staff are recruited, their language proficiency is verified by a university diploma: a university degree always includes proof of language skills in Finnish, Swedish, and one foreign language (Government Decree on University Degrees 794/2004). Members of international staff are usually expected to have competence in English, which must be verified either at the job interview or on the basis of certificates. The types of certificates are not usually specified.

According to the education and research development plan for 2007-2012 issued by the Ministry of Education (2008: 44), universities are expected to require proof of language proficiency from teachers who provide instruction in a foreign language. This may be demonstrated by means of a language proficiency certificate or in some another recognisable manner. However, it seems that such proof is generally not required from non-native teachers, either for teaching in English or for teaching in Finnish. It is up to teachers who are willing to offer classes in a foreign language to judge their own proficiency as sufficient. In my opinion, one reason for avoiding stricter rules concerning official verification of language competences may be that the universities or departments are worried about not being able to recruit enough teachers who are qualified and willing to teach in a foreign language. 
Up until now, Finnish universities have not applied any measures to assess or support the quality of teaching in a foreign language. Hughes (2008) refers to the risks associated with such a vague language policy. One can only share her opinion that the lack of any concrete preparatory and ongoing support measures may be damaging not only to the quality of teaching and the university's own global brand, but also to learning results, due to constraints on the capacity of individuals to operate in a foreign language and unfamiliar academic environment.

\section{Students}

Finnish degree students have to know Finnish and/or Swedish depending on the university's official language(s). Their language competence is officially verified by the national matriculation examination certificate. From the nineteen-seventies until 2004, this matriculation examination was compulsory in both national languages but from 2005 on it has been optional in the second national language due to legislative regulation based on a decision made by the Finnish parliament in 2003. This was a result of ongoing discussions about the state of Swedish in Finnish education and one of the arguments was that voluntariness would increase the motivation to learn Swedish. However, decreasing numbers of voluntary participants in the Swedish matriculation examination proved this argument wrong and the strong aversion against 'pakkoruotsi' ('forced Swedish') in school continues to be a topic of debate. An initiative launched in March 2013 to even change Swedish into an optional subject in school collected the needed 50000 votes to be processed by the Finnish parliament (Helsingin Sanomat, 2013). Also the opposite opinion is expressed by arguing that the matriculation examination should be compulsory in both national languages again because it would increase people's opportunities in the labour market. In fact, it is widely believed to be much easier to get a place at a Swedish-medium university than at a Finnish-medium, as I will show later.

Foreign degree students are usually expected to know English, and in some cases also Finnish and/or Swedish (depending on the university and the study programme). The related language proficiency requirements vary from one university to another. At the Sibelius Academy, for example, detailed requirements are listed for foreign bachelor's and master's degree students, who must provide a certificate for English and Finnish or Swedish. Depending on the study programme, they may also be required to demonstrate sufficient skills in Finnish or Swedish in an entrance examination (Sibelius Academy, 2010). At the University of Jyväskylä (2011), requirements are expressed in more general terms: 'International exchange students have the right to use English for their study completion, unless otherwise provisioned by the curriculum.'

There are also different practices with respect to the language requirements that apply to students who want to study abroad. At Aalto University, for example, Finnish students who apply for university grants to participate in international student exchange programmes have to prove their language proficiency by submitting certificates or taking language tests organised by the Language Centre (Aalto University, 2011). The University of Jyväskylä simply recommends practising or refreshing language skills before going abroad (University of Jyväskylä, 2012b).

There are no explicit requirements for exchange students coming to Finland, although skills in English are usually a prerequisite for participating in courses for foreign students without any knowledge of Finnish or Swedish. 


\section{Administrative staff}

According to the Universities Act 558/2009, Section 35, the language of administration is Finnish and/or Swedish depending on the university (see above, Are language practices regulated in an explicit way?). The language competence of administrative staff is not as clearly regulated as before the 2010 university reform (see above, Are language practices regulated in an explicit way?). Generally, they are expected to know the language(s) required to perform their duties, and it is up to the universities to define language requirements. Depending on the position, English may be a prerequisite for employment. However, in many cases English skills are now tacitly expected of administrative staff. As in the case of teaching and research staff, language competences of administrative staff are officially verified by their matriculation examination certificate. Universities may also apply their own case-specific regulations.

\section{Which languages are used for research?}

\section{Languages of scientific publications}

The Ministry of Education commissioned a project to investigate 'Disciplinary differences in publishing practices'. The results are based on an analysis of publication register data for three Finnish universities for 1998-2005 (University of Helsinki, Helsinki School of Economics, and Tampere University of Technology), and on 44 interviews with lecturers at nine Finnish universities (Puuska \& Miettinen, 2008). Table 4.4 shows the results of an analysis of scientific publication registers. Scientific publications comprise scientific books (i.e. books and special issues or conference proceedings), peer-reviewed scientific journal articles, book sections, papers in conference proceedings, editorials, book reviews, short review articles or non-refereed scientific journal articles in the natural sciences (including the agricultural sciences), medical sciences, engineering, social sciences, and the arts and humanities.

Table 4.4 Scientific publications at three Finnish universities for 1998-2005: country and language of publication

\begin{tabular}{|l|l|l|l|l|l|}
\hline Country & No. & $\%$ & Language** & No. & $\%$ \\
\hline Finland & 24,111 & 39 & English & 39,998 & 65 \\
\hline USA & 11,347 & 18 & Finnish & 18,223 & 30 \\
\hline UK & 6,639 & 11 & Swedish & 1,272 & 2.1 \\
\hline The Netherlands & 3,421 & 6 & German & 794 & 1.3 \\
\hline Germany & 3,219 & 5 & Russian & 348 & 0.6 \\
\hline Denmark & 1,319 & 2.1 & French & 266 & 0.4 \\
\hline Sweden & 1,227 & 2 & Spanish & 142 & 0.2 \\
\hline Switzerland & 776 & 1.3 & Estonian & 133 & 0.2 \\
\hline Norway & 736 & 1.2 & Italian & 120 & 0.2 \\
\hline France & 726 & 1.2 & Hungarian & 56 & 0.1 \\
\hline Other & 5,679 & 10 & Other & 267 & 0.4 \\
\hline Total & 59,200 & 100 & Total & 61,404 & \\
\hline Not specified* & 2,204 & & & & \\
\hline
\end{tabular}


Source: Puuska \& Miettinen (2008: 26). * Not given / ** Some publications are multilingual.

Almost $40 \%$ of all the scientific publications analysed were published in Finland, but in $65 \%$ of cases the language of publication was English, and in 30\%, Finnish (see Table 69). Seventeen percent of the works published in Finland were written in a language other than Finnish or Swedish, and most of the works published abroad were written in English (91\%). The results also showed that in natural and medical sciences the language of publications was invariably English. In engineering, in areas closely linked to international industry, such as communications technology, biotechnology and electronics, many articles were published in international refereed journals and, without exception, were written in English. In the social sciences, however, the number of international publications had increased significantly, while the number of domestic publications and publications in Finnish had decreased over 1998-2004. Non-scientific publications were analysed separately; most were published in Finland (95\%) and in Finnish (83\%) (Puuska \& Miettinen 2008: 26-36). In another comparative study the number of publications in Finnish was found to be higher for state research institutes than for universities (Puuska \& Late, 2010).

\section{Languages of PhD dissertations}

Universities have their own regulations for public examination of doctoral theses. At the University of Jyväskylä, for example, the language used for the oral defence of a $\mathrm{PhD}$ dissertation may be chosen in advance by the custos (the chairman of the public dissertation defence) by mutual agreement with the candidate and the opponent. Many language choices are possible, from Finnish or Swedish to some other language, or even several languages:

The language used in the public examination (defence) of the doctoral dissertation is determined by the custos in advance, after he/she has discussed the matter with both the doctoral candidate and the opponent. The language of the public examination shall be Finnish or Swedish or the language in which the doctoral dissertation was published. It is, however, possible to hold the public examination of the dissertation in some other language, if the doctoral candidate agrees to it, or to use several languages in the public examination, if it has been agreed upon in advance. (University of Jyväskylä 2011, highlighted by the author)

To explore the languages in which $\mathrm{PhD}$ dissertations have been written, my research centre ${ }^{1}$ enabled me to purchase the register of all $\mathrm{PhD}$ dissertations in Finland from the FENNICA database, which contains 45,592 titles. The Finnish National Bibliography (FENNICA) records publications in Finland (books since 1488, journals since 1771, as well as periodicals, maps, and audiovisual and electronic data). The register contained all $\mathrm{PhD}$ dissertations from the 17th century on. However, almost 4000 (3924) titles were listed twice (for example, when the dissertation was published in both print and electronic versions). These duplicates were deleted and the publication years were coded in order to analyse the data statistically.

For this chapter, I first looked at the languages in which dissertations were written from the 17th century until the end of 2009 (see Figure 4.4), and then at PhD dissertations in the past 40 years, applying a shorter interval of ten years (see Figure 4.5). 


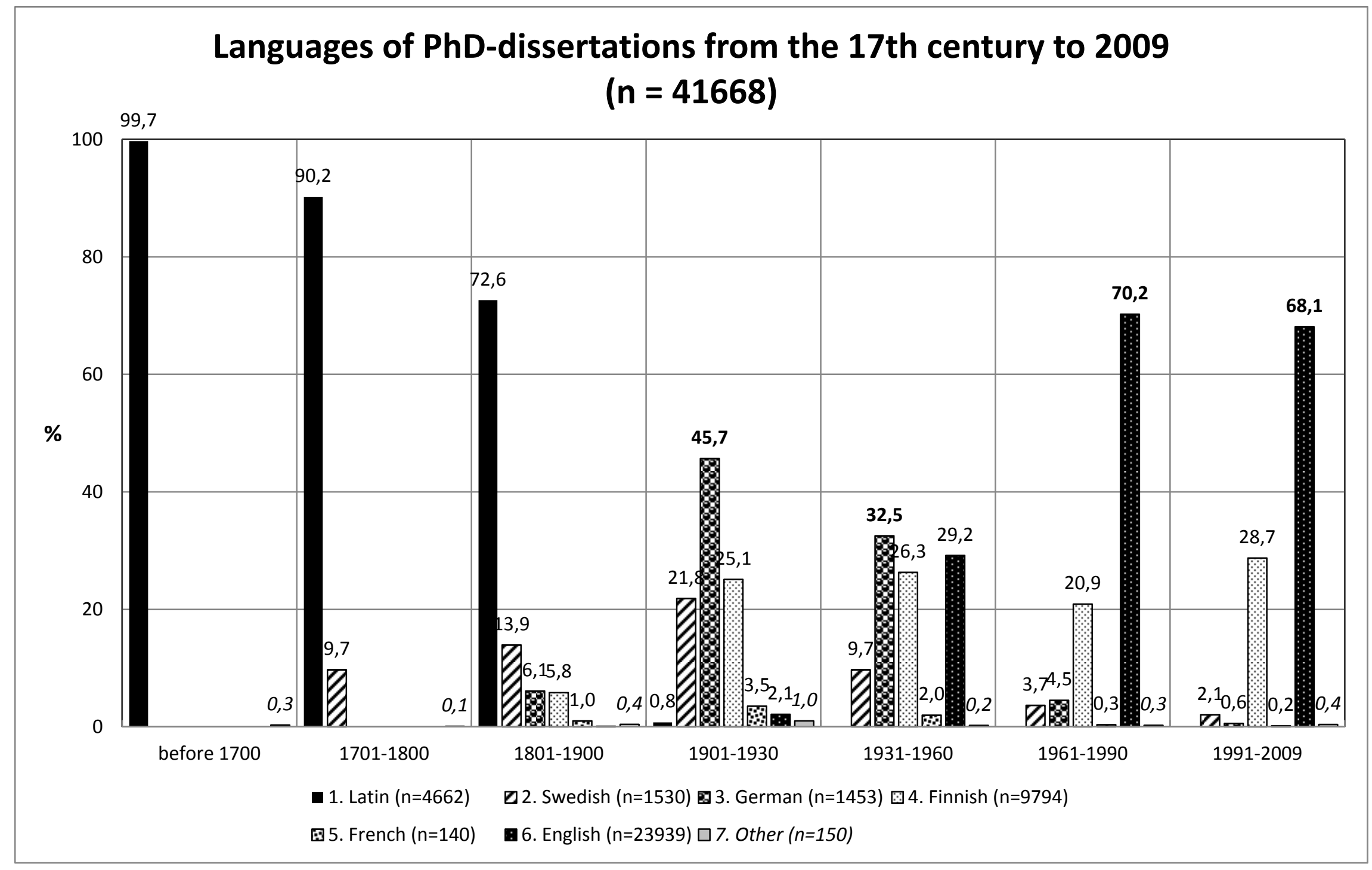

Figure 4.4 Language of PhD dissertations from the 17th century to 2009 (Based on data received from the Finnish National Bibliography [FENNICA]) 
The first university in Finland was founded in Turku in 1640 (the Royal Academy of Turku, then relocated to Helsinki in 1827). The first $\mathrm{PhD}$ dissertation listed in the FENNICA database dates to 1642. The analysis of all $\mathrm{PhD}$ dissertations listed in the database revealed that Latin predominated until 1900. Swedish began to be used in the 18th century, and Finnish in the 19th century, but it was only from the 20th century on that the latter retained a relatively stable share of over $20 \%$. The first half of the last century was the most multilingual. This was also the period when German was the most important language of science. In the first 30 years, five languages were each used for more than 2\% of dissertations, with English accounting for the lowest proportion (2.1\%), topped by French (3.5\%), Swedish (21.8\%), Finnish (25.1\%), and German (45.7\%). However, two world wars and the inhuman policies of the Third Reich led to German gradually losing its popularity as a language of science. A boycott of the language had already begun after World War I (Reinbothe, 2006), and many Jewish scientists emigrated to the US, where they continued their work in English. From 1931 to 1960, English was used for 29.2\% of PhD dissertations in Finland, but German still held the 'pole position' with 32.5\%. From the 1960s on, the number of dissertations in English increased rapidly and it took a clear lead as the most important language. Finnish sank to its lowest percentage, accounting for only one-fifth of all dissertations, and Swedish reached 3.7\%. In the past 20 years, however, Finnish has regained a bit more ground, and together the national languages (Finnish and Swedish) have been used in almost one-third of all $\mathrm{PhD}$ dissertations. A more detailed analysis the languages used to write $\mathrm{PhD}$ dissertations in recent years is shown in Figure 4.5.

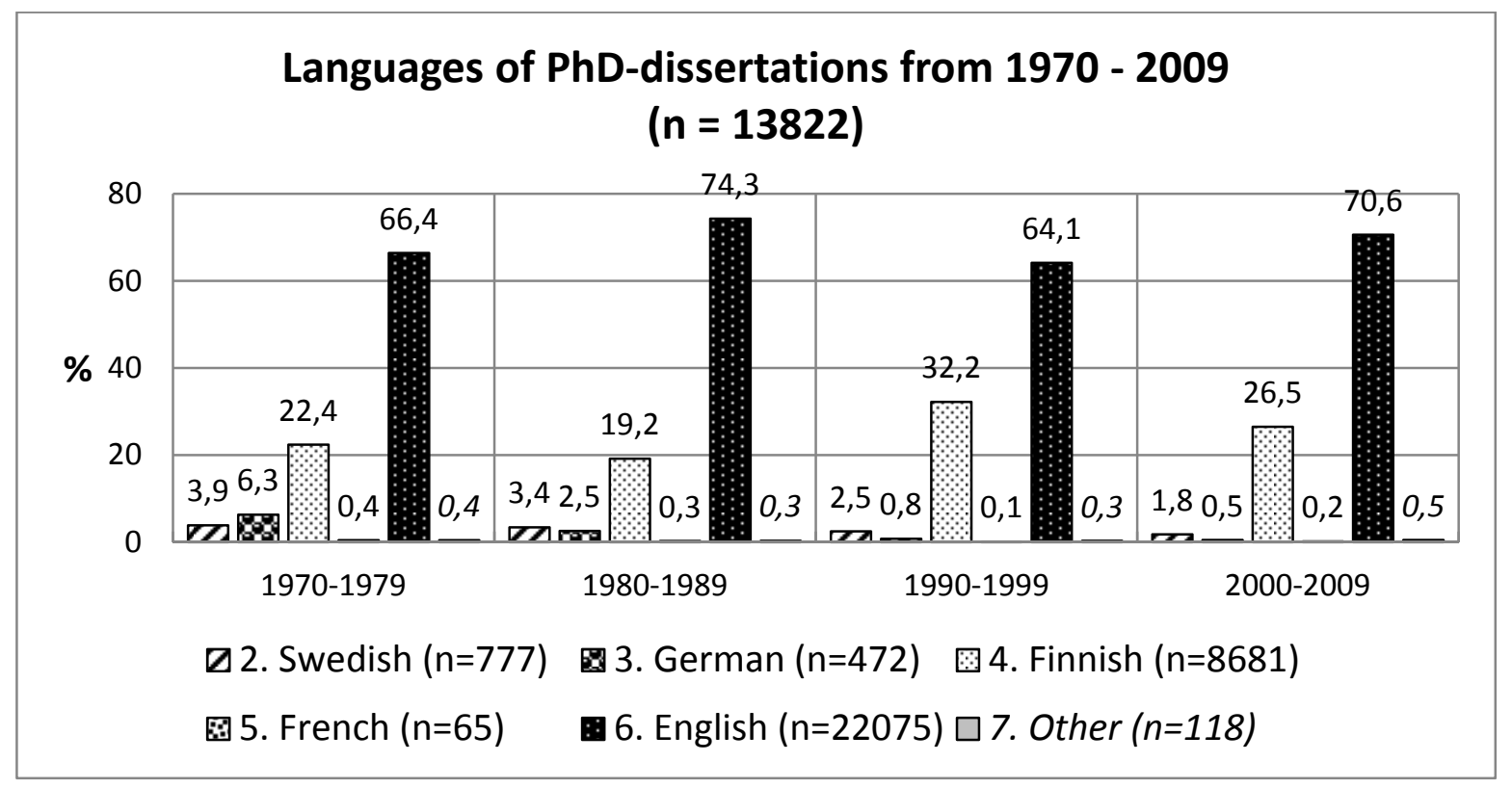

Figure 4.5 Language of $\mathrm{PhD}$ dissertations in the past forty years (Based on data received from the Finnish National Bibliography [FENNICA])

The results of the analysis of the past 40 years show that $\mathrm{PhD}$ dissertations have been written mostly in English since the 1970s, with the language now accounting for over 60\% of the total. At the end of the last century, almost a third of all dissertations were written in Finnish, but their number decreased slightly at the beginning of this century. The number of dissertations written in 
German was only slightly over 6\% in the 1970s, which was nevertheless still slightly higher than the figure for Swedish, but the proportion of dissertations in the language fell below that for Swedish from the 1980s on. The number of dissertations in both Swedish and German has continued to fall steadily up to the present. Other languages are used only to a very limited extent. To sum up, nowadays English and Finnish are practically the only languages used for writing PhD dissertations, with English being used in over $70 \%$ of cases. An analysis of discipline-specific language use in dissertations could not be performed within the framework of this study and will need to be carried out in future investigations.

In the next section, I will examine the main discourses about languages policy at university level and look at the social sectors that support each discourse.

\section{Discourses about Language Policies at University Level}

Current discourses about language policy at university level focus two issues: the role of Swedish as an academic language, and the role of English in relation to the national languages.

An extensive discussion of the role of Swedish in Finnish society is currently going on in the media. This debate, initiated by the Confederation of Finnish Industries (the leading business organisation in Finland), has also affected universities. Under the new Universities Act, for example, skills in both Finnish and Swedish are no longer a general requirement for university staff. There has also been a heated debate about whether there are better possibilities for native speakers of Swedish compared to native Finnish speakers to study at a university. This debate is unfolding in various online forums especially. The discussion was initiated by news circulated by the Finnish Broadcasting company (Yle uutiset, 2011). They claimed that there were 'controversial estimations' regarding admissions to study at universities and universities of applied sciences. The main thrust of the news story was that only one third of native Finnish speakers were gaining admission as compared to fifty per cent of native Swedish speakers. This article also stated that access to study in Swedish has been possible with eight points less in the entry examination than access to study in Finnish. However, the article also quoted the Finnish Ministry of Education and Culture's Permanent Secretary who stated that quotas for studying in Swedish and Finnish aim at ensuring bilingualism and safeguarding services in Swedish. After all, such quotas are not made specifically for native speakers of Swedish or Finnish but to ensure that there are opportunities for studying in these languages, independent of one's mother tongue.

The role of English in the Finnish academic sphere is dominant to such a degree that it forces one to reflect on the role of the national languages in higher education. There has even been recent public debate on whether or not to introduce English as one of the primary languages of teaching, and perhaps even administration. This was suggested by Jacobs (2010). The responses to Jacobs have stressed that switching to English in universities in Finland is not only impossible for legislative reasons, but that it would also conflict with the fact that the majority of students will need to operate in the national languages, Finnish and Swedish, in their working environment in Finland after they graduate from university (Hall, 2010; Vänskä, 2010). In addition, Vänskä (2010) criticises Jacobs’s attitude as being based on the belief that English is more neutral and natural than other languages. In her opinion, this view is quite naïve and indicates several gaps in Jacobs's education since this is 
usually the way one feels about a native language. She also points to the fact that language is needed for thinking and the construction of knowledge in the natural sciences too (Vänskä, 2010).

Hakulinen (2009) states that the undeclared policy of Finnish scientific institutions favours the use of English. She continues that the Finnish language can survive if we (i. e. academics in Finland) decide that it must and support this decision in practice. The Research Institute for the Languages of Finland, for example, has published an appeal aimed at defending Finnish as the language of science and higher education (Luukka, 2010), and the Centre for International Mobility in Finland (CIMO) has recently emphasised the promotion of learning and teaching Finnish as a foreign language, both within Finland and abroad (Ketolainen et al., 2010).

Cases that concern the right to study in one's mother tongue, Finnish or Swedish, have been discussed in the media. For example, at the University of Turku, two lecturers were recently appointed for the subjects of geology and mineralogy. Both were foreigners (one from Sweden, the other from the Netherlands) and both lacked skills in Finnish. Some of the issues considered were the importance of the mother tongue for learning and the right under the Finnish Constitution to study in one's mother tongue, Finnish or Swedish (Saarnisto, 2001). Another case discussed in the media concerned a complaint against the University of Helsinki made by a student to the Office of the Chancellor of Justice about the fact that Finnish students were required to use English in all their studies at the Faculty of Agriculture and Forestry if there was even a single foreign student in the group. The student claimed that this procedure contravened the Finnish Constitution (Yle, 2010). The Office ruled against the student, making reference to the Universities Act, which allows universities to use a language other than Finnish and/or Swedish for tuition (OKV/1001/1/2009). A recent complaint to the Office of the Chancellor of Justice was made by a student of the School of Business at Aalto University concerning its decision to teach all master programmes in English. In his opinion this contravenes the university act. Aalto University justified its decision by stating that studies in bachelor programmes are offered in Finnish, and the university aims to enrol more international students at master's level. This decision was motivated by the wish to strengthen internationalisation as a strategic alignment. Furthermore, Aalto University wants to entice promising young researchers. Their aim is an increase in quality through internationalisation. (Yle, 2013a). The legal procedure is still underway as I write but the Finnish Ministry of Education and Culture has gauged that the University Act is possibly in need of change (Yle, 2013b).

At the initiative of Universities Finland, the 'Publication Forum Project' was launched in 2010 (Federation of Finnish Learned Societies, 2010). The project, funded by the Ministry of Education and Culture, aimed at establishing a 'quality classification' for scientific publication channels in all research fields. In principle, it offered the possibility of incorporating language policy considerations in the national policy for assessing the quality of scientific publications. However, the rating results published in January 2012 only reinforced the dominant role of English, because journals classified as Level 3 (top publication channels in their field) and Level 2 (leading scientific publication channels) were mainly in English. Publications in languages other than English made it only to Level 1 (domestic and foreign scientific publication channels). The plan is to take this rating into account in allocating resources (more money to higher-level publications; see Ministry of Education and Culture, 2011b: 41), so the dominance of English is likely to become even stronger. As a result, sixty scientific societies signed a declaration in favour of diversified and multifaceted 
publication principles, questioning both the rating levels and the Ministry's plan to use them as a funding criterion (Finnish Youth Research Society, 2012). In response, the door to Level 2 was opened in principle also for domestic publication channels in spring 2012 (Sintonen, 2012:6). In contrast, the use of English as the language for research funding applications has not yet been questioned. The Academy of Finland, for example, recommends that funding applicants submit applications in English, despite their basic right to use Finnish or Swedish. This is justified by the practice of recruiting mainly foreign experts as scientific reviewers.

\section{Summary and Conclusions}

The status of Finnish and Swedish as national languages in Finland is regulated in the Finnish Constitution and the Language Act, as well as by several acts and decrees in specific societal domains, including the Universities Act. The official bilingual status of the country grants everyone the right to use Finnish or Swedish in matters that concern them, and to obtain documents in the language they use. On the other hand, as medium-sized national languages, neither Finnish nor Swedish are very well suited for the purposes of internationalisation in higher education. This is why foreign language skills have traditionally been very highly valued in Finland. However, growing competition has led to a rapid increase in the importance of English in the Finnish academic sphere, whether as a language of teaching (to recruit more foreign students) or as the preeminent lingua franca in research. Like many other countries, Finland also has to address the challenges of internationalisation and competition, which affect national languages as well as the status of foreign languages other than English.

The new government strategy for the national languages of Finland (Prime Minister's Office, 2012) is the first of its kind. Its aim is to safeguard the bilingual nature of the country, and especially to support the minority language Swedish. The growing influence of English is referred to in the context of recommendations to use Finnish and Swedish 'in all walks of life' to 'maintain diverse and nuanced vocabulary and expressions' (Prime Minister's Office, 2012: 9). In terms of foreign languages other than English, the goals to enlarge the language resources of the country, as set out earlier in the programme of Prime Minister Jyrki Katainen's government (Prime Minister's Office, 2011: 51, 53), are not pursued. The 2011-2016 programme for the development of education and research, for example, emphasised versatile language and cultural competences as being needed in all areas of our increasingly internationalising society. The authors point out that, in line with the requirements of globalisation, the learning of foreign languages at school 'has been overly focused on the English language' (Ministry of Education and Culture, 2012: 18). Finland's government language strategy does not touch upon this topic. With regard to science communication, the strategy characterises the use of English as 'a natural development'. Despite the fact that the strategy does not include any proposals for reform of legislation, the Finnish Ministry of Education and Culture has gauged that the university act is possibly in need of change because of the ever strengthening position of English at Finnish universities. The latest complaint of a student against the Aalto University's decision to teach all master programmes in English is still being processed by the Office of the Chancellor of Justice. ${ }^{2}$

According to the Ministry of Education (2008: 44), universities in Finland are expected to develop language policies for their own purposes. Our analysis showed that half of the universities had 
developed such policies by January 2012 and $71 \%$ by 2013. These language policies were developed by the universities independently from each other, and there does not appear to have been any cooperation. Moreover, the language policy documents have different names and are available in one to three languages: Finnish, Swedish and English; Finnish and English; Swedish and English; or a single language, either Finnish or Swedish. They differ in content and length but all emphasise the role of English for internationalisation, without overlooking the legislative status of the national languages. Foreign languages other than English are usually referred to rather vaguely. In January 2012, only one university (Helsinki) mentioned the importance of publishing in foreign languages other than English, and two more universities (Turku and Tampere) postulated the same in their new language policies developed later in 2012 and 2013. Concrete measures to implement the language policies were included only in a minority of cases and focused especially on strengthening the role of English in teaching, publishing of research results, and administration. However, there seems to be a tendency towards more concrete definitions of objectives and measures in the three newer language policies developed in 2012 and 2013. Interestingly, two universities (Tampere and Turku) espouse wider use of different languages, and, in contrast, one other (Tampere University of Technology) emphasises the role of English to promote its internationalisation.

Although Finnish legislation guarantees the status of the national languages for tuition and administration, assessment and auditing procedures at the internal, national and international level clearly favour English in higher education and research. For example, universities are encouraged to offer foreign language teaching to attract foreign students, and today a foreign language invariably means English. At the same time, there are still no concrete measures to ensure the language competence of staff teaching in a foreign language. Also, in research the use of English is clearly favoured and rewarded. As long as concrete measures for valuing and supporting the national languages and foreign languages other than English are lacking, language policies remain no more than bits of paper that articulate good intentions. One university, for example, justified the fact that it did not have a language policy by arguing that it lacked the resources needed to take concrete measures. On the other hand, opportunities to develop concrete measures for promoting the use of the national languages and foreign languages other than English are far too often missed, as shown in the discussion about the national publication forum project. One could ask whether English is the only key to internationalisation and how the use of terms such as 'natural development' could escape critical scientific gaze. A more in-depth reflection on the interdependence of thinking, language and the socio-cultural construction of knowledge (see Ylönen, 2011) beyond the vocabulary dimension would advance the status of the national languages and foreign languages other than English.

Acknowledgements: Thanks are due to Elina Laajala for eliminating double listings of $\mathrm{PhD}$ dissertations and coding the years of publication, and to Helena Mackay and Marilyn Martin-Jones for proofreading different drafts of the chapter.

\section{References}

Aalto University 2011. Kansainvälistyminen ja opinnot ulkomailla - Vaihto-opiskelu: Kielitaidon osoittaminen (Internationalisation and studies abroad - exchange studies: Demonstration of 
Aalto University 2010. Aalto University Language Guidelines. Received via personal e-mail (Leena Plym-Rissanen) 18.10.2011.

Act on the Language Skills of Civil Servants 149/1922. Original: Laki Valtion virkamiehiltä vaadittavasta $\quad$ kielitaidosta. $\quad$ Finlex [17.1.2012] http://www.finlex.fi/fi/laki/alkup/1922/19220149

Act on the Knowledge of Languages Required of Personnel in Public Bodies 424/2003. Original: Laki julkisyhteisöjen henkilöstöltä vaadittavasta kielitaidosta. Finlex [17.1.2012] http://www.finlex.fi/fi/laki/alkup/2003/20030424

Amendment 715/2004. Amendment to the Universities Act 645/1997. Original: Laki yliopistolain muuttamisesta 715/2004. Finlex [17.1.2012] http://www.finlex.fi/fi/laki/alkup/2004/20040715

Brenn-White, Megan \& van Rest, Edwin 2013. English-Taught Master's Programs in Europe: A 2013 Update. New York: Institute of International Education [2.10.2013] http://www.iie.org/ /media/Files/Corporate/Publications/English-Language-Masters-2013Update.ashx

Brenn-White, Megan \& van Rest, Edwin 2012. English-Taught Master's Programs in Europe: New Findings on Supply and Demand. New York: Institute of International Education [29.8.2013] http://www.iie.org/Research-and-Publications/Publications-and-Reports/IIE-Bookstore/EnglishLanguage-Masters-Briefing-Paper

CIMO 2011. Ulkomaiset tutkinto-opiskelijat korkeakouluissa suhteessa opiskelijamäärään 20022010. (Foreign degree students in Finnish higher education institutions in relation to the total number of students). Helsinki: CIMO - Centre for International Mobility. [1.2.2012] http://www.cimo.fi/instancedata/prime_product_julkaisu/cimo/embeds/cimowwwstructure/21342_ UTO_suhteessa20022010.pdf

Decree on demonstrating proficiency in Finnish and Swedish for public administration 481/2003. Original: Valtioneuvoston asetus suomen ja ruotsin kielen taidon osoittamisesta valtionhallinnossa 481/2003. Finlex

[17.10.2011] http://www.finlex.fi/fi/laki/alkup/2003/20030481

Finnish Constitution 731/1999. Unofficial translation of 'Suomen perustuslaki 11.6.1999/731'. Finlex [12.10.2011] http://www.finlex.fi/en/laki/kaannokset/1999/en19990731.pdf (Original: http://www.finlex.fi/fi/laki/ajantasa/1999/19990731 )

Finnish Youth Research Society 2012. Monipuolisen ja -muotoisen tieteellisen julkaisutoiminnan puolesta. (For diversified and multifaceted publishing) [02.02.2012] http://www.nuorisotutkimusseura.fi/sites/default/files/tapahtumatiedostot/Kannanotto_lopullinen.pd $\mathrm{f}$ 
Garam, Irma \& Korkala, Siru 2011. International mobility in Finnish vocational and higher education in 2010. Helsinki: CIMO - Centre for International Mobility. [1.2.2012] http://www.cimo.fi/instancedata/prime_product_julkaisu/cimo/embeds/cimowwwstructure/21273_F aktaa_1b_2011_web.pdf

Garam, Irma 2009. Degree programmes taught through a foreign language in Finnish higher education. Faktaa - Facts and Figures 2b/2009. Helsinki: CIMO - Centre for International Mobility. http://www.cimo.fi/instancedata/prime_product_julkaisu/cimo/embeds/cimowwwstructure/15610_d egree_programmes_faktaa_summary.pdf

Government Decree 770/2009. Original: Valtioneuvoston asetus yliopistoista (Government Decree on $\quad$ Universities). Finlex

[17.10.2011] http://www.finlex.fi/fi/laki/alkup/2009/20090770

Government Decree on University Degrees 794/2004. Original: Valtioneuvoston asetus yliopistojen tutkinnoista. Finlex

[17.10.2011] http://www.finlex.fi/fi/laki/alkup/2004/20040794

Government Decree 463/1998. Original: Asetus korkeakoulujen henkilöstön kelpoisuusvaatimuksista ja tehtävistä annetun asetuksen muuttamisesta 463/1998. Finlex [17.10.2011] http://www.finlex.fi/fi/laki/alkup/1998/19980463

Hakulinen, Auli 2009. Kielipolitiikka ja suomalainen tiede. (Language policy and Finnish science.) Academia Scentiarum Fennica http://www.acadsci.fi/tiedostot/vuosikirja_2009/hakulinen_esitelma.pdf

Hall, C. 2010. Suomalaiset yliopistot englanninkielisiksi? Acatiimi 6/10: 23-24.

Helsingin Sanomat 2013. Aloite pakkoruotsin poistamisesta ei saa hallituspuolueiden kannatusta. (The initiative to remove compulsory Swedish does not receive support from the government parties). Helsingin Sanomat 12.8.2013 [5.9.2013] http://www.hs.fi/politiikka/a1376273063752

Hughes, Rebecca 2008. Internationalisation of Higher Education and Language Policy: Questions of Quality and Equity. Higher Education Management and Policy, Volume 20, Number 1, January 2008: 102-119.

Jacobs, H. 2010. United by an uncommon language. Acatiimi 4/10: 28-29. [5.10.2010.] http://www.acatiimi.fi/4_2010/04_10_11.php

Federation of Finnish Learned Societies 2010. Julkaisufoorumi (Publication forum) 2010. [29.4.12] http://www.tsv.fi/julkaisufoorumi/

Ketolainen, J.; Kopperi, M.; Siltala, A.; Vehkanen, M. \& Daavittila, T. (Ed.) 2010. CIMO korkeakoulutuksen kansainvälistäjänä 2009 (CIMO as a Promoter of Internationalization in Higher Education). Helsinki: Centre for International Mobility CIMO. [5.10.2010] http://www.cimo.fi/dman/Document.phx/ public/Julkaisut+ja+tilastot/Esitteet+suomenkieliset/TA2 _2009.pdf 
Language Act 423/2003. Unofficial translation of 'Kielilaki 6.6.2003/423’ Finlex. [17.10.2011] http://www.finlex.fi/en/laki/kaannokset/2003/en20030423.pdf

(Original:

http://www.finlex.fi/fi/laki/ajantasa/2003/20030423)

Luukka, Minna-Riitta 2010. Vetoomus suomen kielen turvaamiseksi tieteen ja korkeimman opetuksen kielenä (Appeal for safeguarding the status of Finnish as a language of science and higher education). Kotimaisten kielten tutkimuskeskus. Suomen kielen lautakunta. (Research Institute for the Languages of Finland. Finnish language board.). [17.10.2011] http://www.kotus.fi/files/1429/Vetoomus_lautakunta_2010.pdf

Ministry of Education 2009a. Strategy for the internationalisation of higher education institutions in Finland 2009-2015. [14.1.2012.]

http://www.minedu.fi/export/sites/default/OPM/Julkaisut/2009/liitteet/opm23.pdf

Ministry of Education 2009b. Key competences for lifelong learning in Finland, Education 2010 interim report.

[1.2.2012]

http://www.minedu.fi/export/sites/default/OPM/Koulutus/Liitteet/Education_2010._Interim_report_ 2009._Finland.pdf

Ministry of Education 2008. Education and research 2007-2012. Development Plan. [12.10.2008] http://www.minedu.fi/export/sites/default/OPM/Julkaisut/2008/liitteet/opm11.pdf?lang=fi

Ministry of Education and Culture 2012. Education and Research 2011-2016. A development plan.) [28.9.2012] http://www.minedu.fi/export/sites/default/OPM/Julkaisut/2012/liitteet/okm03.pdf.

Ministry of Education and Culture 2011a. Korkeakoulut 2011 - yliopistot ja ammattikorkeakoulut. (Higher education institutions 2011 - universities and polytechnics) [02.02.2012] http://www.minedu.fi/export/sites/default/OPM/Julkaisut/2011/liitteet/okm10.pdf?lang=fi

Ministry of Education and Culture 2011b. Laadukas, kansainvälinen, profiloitunut ja vaikuttava yliopisto - ehdotus yliopistojen rahoitusmalliksi vuodesta 2013 alkaen. (High-quality, international, specialized and influential university - proposal for a university financing model from 2013 on) [02.02.2012]

http://www.minedu.fi/export/sites/default/OPM/Julkaisut/2011/liitteet/okmtr26.pdf

OKV/1001/1/2009. Englannin käyttäminen yliopiston opetuskielenä. (Use of English as a language of tuition.). Apulaisoikeuskanslerin päätös (Decision of the Deputy Chancellor of Justice): 25.11.2010. [12.10.2011] http://www.finlex.fi/fi/viranomaiset/foka/2010/20101621

Prime Minister's office 2011. Programme of Prime Minister Jyrki Katainen's Government. Helsinki: Finland. http://valtioneuvosto.fi/hallitus/hallitusohjelma/pdf/en334743.pdf [28.9.2012]

Prime Minister's office 2012. Strategy for the national languages of Finland. Government resolution. Helsinki: Prime Minister's Office Publications 7/2012. [2.10.2013] http://vnk.fi/julkaisukansio/2012/j04-kansalliskielistrategia-nationalsspraksstrategi-j07strategy/PDF/en.pdf 
Puuska, Hanna-Mari and Late, Elina 2010. Julkaisukäytännöt yliopistoissa ja valtion tutkimuslaituoksissa: kolmen tieteenalan vertailu. (Publishing practices at universities and national research institutions). Abstract. Informaatiotutkimus (Information studies) 29/3: Informaatiotutkimuksen päivät 2010 (Conference on Information studies 2010) [10.2.2012] http://ojs.tsv.fi/index.php/inf/article/viewFile/3601/3353

Puuska, Hanna-Mari and Miettinen, Marita 2008. Julkaisukäytännöt eri tieteenaloilla. (Disciplinary differences in publishing practices). Opetusministeriön julkaisuja (Publications of the Ministry of Education) 2008:33. Helsinki: Helsingin yliopistopaino. [12.10.2011] http://www.minedu.fi/export/sites/default/OPM/Julkaisut/2008/liitteet/opm33.pdf?lang=fi

Reinbothe, R. 2006. Deutsch als internationale Wissenschaftssprache und der Boykott nach dem Ersten Weltkrieg. Duisburger Arbeiten zur Sprach- und Kulturwissenschaft 67. Frankfurt/M: Lang.

RIC (Research and Innovation Council of Finland) 2009. Internationalisation of Finnish Education, Research and Innovation.

[3.2.2012]

http://www.minedu.fi/export/sites/default/OPM/Tiede/tutkimus-

_ja_innovaationeuvosto/erillisraportit/liitteet/KVstrategia_Eng.pdf

Saarinen, Taina 2012. Internationalization and the invisible language? Historical phases and current policies in Finnish higher education. In: Ahola, Sakari and Hoffman, David (ed.). Higher education research in Finland. Emerging structures and contemporary issues. Jyväskylä: Finnish Institute for Educational Research, 235-248.

Saarnisto, Matti 2001. Millä kielellä yliopistossa opiskellaan? (In which language do we study at the university?) Tieteessä tapahtuu (Science now) 2001/3 [15.10.2011] http://www.tieteessatapahtuu.fi/013/paakirjoitus.htm

Sibelius Academy 2010. Guide for International Applicants 2011. Helsinki: Sibelius Academy Website [24.10.2011] http://www.siba.fi/en/c/document_library/get_file?uuid=09a3583b-0bc0-4744-b9a8a1f3ee201537\&groupId=10157

Sintonen, Kirsti 2012: Julkaisufoorumin tasoluokitusta muutettiin [The criteria for classification in the publication forum were changed]. Acatiimi 2 (2012): 6. [23.4.2012] http://www.acatiimi.fi/2_2012/02_12_03.php.

Statistics Finland 2013. Appendix table 2. Population according to language 1980-2012. [15.8.2013] http://www.stat.fi/til/vaerak/2012/vaerak_2012_2013-03-22_en.pdf

The Office of the Chancellor of Justice (2013). Anonymisoitu päätös [Anonymised decision] Dnro OKV/727/1/2013. See http://www.oikeuskansleri.fi/media/uploads/ratkaisut/ratkaisut 2013/okv 727 1 2013.pdf (accessed 26 August 2014). 
Universities Act 558/2009. Unofficial translation of 'Yliopistolaki 24.7.558/2009' Finlex

[15.8.2013] http://www.finlex.fi/en/laki/kaannokset/2009/en20090558.pdf ～(Original: http://www.finlex.fi/fi/laki/ajantasa/2009/20090558)

Universities Act 645/1997. Unofficial translation of 'Yliopistolaki 645/1997'. Finlex [12.10.2011] http://www.finlex.fi/en/laki/kaannokset/1997/en19970645.pdf

(Original:

http://www.finlex.fi/en/laki/kaannokset/1997/en19970645.pdf)

University of Helsinki 2007. University of Helsinki Language Policy. [12.10.2011] http://www.helsinki.fi/inbrief/strategy/HYn_kieliperiaatteet.pdf

University of Eastern Finland 2011. Itä-Suomen yliopiston kielipoliittinen ohjelma vuosiksi 20112015. (Eastern-Finland university language policy 2011-2015) Received vial personal e-mail message (Raija Elsinen) 7.12.2011.

University of Jyväskylä 2012a. Jyväskylän yliopiston kielipolitiikka (Jyväskylä university language policy).

[2.2.2012]

https://www.jyu.fi/hallinto/strategia/politiikat/Jyvaeskylaen\%20yliopiston\%20kielipolitiikka\%2025 012012.pdf

University of Jyväskylä 2012b. Tietoa ulkomaille lähteville (Information for students going abroad) [2.2.2012]

https://www.jyu.fi/hallintokeskus/opiskelijoille/oppaat/tietoa_ulkomaille_lahteville/referencemanua l-all-pages

University of Jyväskylä 2011. Degree Regulations of the University of Jyväskylä, Chapter 6, Section 29: Language used in the public examination of doctoral dissertation. [24.10.2011] https://www.jyu.fi/opiskelu/degreereg

University of Jyväskylä 2004. Jyväskylä university language policy. [2.2.2012] https://www.jyu.fi/hallinto/strategia/en/JY_languagepolicy.pdf

Välimaa, Jussi; Fonteyn, Katarzyna; Garam, Irma; van den Heuvel, Ether; Linza, Christina; Söderqvist, Minna; Wolff, Jan Uwe \& Kolhinen, Johanna 2013. An Evaluation of International Degree Programmes in Finland. Helsinki: Publications of The Finnish Higher Education Evaluation Council 2:2013. [29.8.2013] http://www.kka.fi/files/1822/KKA_0213.pdf

Vänskä, Annamari 2010. Kieli-imperialismia (Language imperialism). Yliopisto 10/2010: 54

Wächter, Bernd \& Maiworm, Friedhelm 2008. English-Taught Programmes in European Higher Education. The Picture in 2007. ACA Papers on International Cooperation in Education. Bonn: Lemmens.

Yle 2010. Englannin kielen ylivalta johti kanteluun Helsingin yliopistosta (Domination of English led to a complaint against the University of Helsinki) Yle uutiset (public-broadcasting/Yle news) 17.3.2010. Helsinki: Yle (Finnish Broadcasting Company). [2.10.2011] http://yle.fi/uutiset/kulttuuri/2010/03/englannin_kielen_ylivalta_johti_kanteluun_helsingin_yliopist osta_1537907.html 
Yle 2011. Yliopistojen ovet aukeavat helmpommin ruotsinkielisille (The doors of universities open easier for speakers of Swedish). Helsinki: Yle (Finnish Broadcasting Company). 3.10.2011 [19.8.2013] http://yle.fi/uutiset/yliopistojen_ovet_aukeavat_helpommin_ruotsinkielisille/2914002

Yle 2013a. Kauppakorkeakoulu hylkäsi suomen - maisteriopinnot vain englanniksi (The School of Business abandoned Finnish - master studies in English only). Helsinki: Yle (Finnish Broadcasting Company). 16.2.2013 [19.8.2013] http://yle.fi/uutiset/kauppakorkeakoulu_hylkasi_suomen__maisteriopinnot_vain_englanniksi/6494336

Yle 2013b. Opetusministeriö: Yliopistolakia ehkä muutettava englanninkielisen opetuksen takia. (Ministry of Education: Universities act may have to be changed because of teaching in English). 25.2.2013. Helsinki: Finnish Broadcasting Company Yle. [19.8.2013] http://yle.fi/uutiset/opetusministerio_yliopistolakia_ehka_muutettava_englanninkielisen_opetuksen _takia/6508928

Ylönen, Sabine 2011. Denkstil und Sprache/n in den Wissenschaften. Mit Beispielen aus der Medizin. Zeitschrift für Angewandte Linguistik 55: 1-22

Ylönen, Sabine \& Kivelä, Mari 2011. The role of languages at Finnish universities. Apples Journal of Applied Language Studies 5/3 2011: 33-61. [1.2.2012] http://apples.jyu.fi/article_files/Ylonen_Kivela_final.pdf

Ylönen, Sabine \& Vainio, Virpi 2010. Mehrsprachigkeit und Rolle des Deutschen im Studium aus der Sicht finnischer Studierender. Apples - Journal of Applied Language Studies 4/1 2010: 29-49. [1.2.2012] http://apples.jyu.fi/ArticleFile/download/116 


\section{Appendices}

Appendix 4.1 Languages of instruction and examination as regulated by Finnish legislation

\begin{tabular}{|c|c|c|}
\hline Finnish $(9+1 *)$ & Swedish $(2+1 *)$ & Finnish \& Swedish (3) \\
\hline University of Eastern Finland & Åbo Akademi University & University of Helsinki \\
\hline University of Lapland & Hanken School of Economics & $\begin{array}{l}\text { Aalto University (formed by the } \\
\text { merger of the University of Art } \\
\text { and Design, the Helsinki School } \\
\text { of Economics and Helsinki } \\
\text { University of Technology) }\end{array}$ \\
\hline University of Jyväskylä & & \multirow{3}{*}{$\begin{array}{l}\text { Arts University (in 2013) } \\
\text { (before 2013: Sibelius Academy } \\
\text { Academy of Fine Arts } \\
\text { Theatre Academy) }\end{array}$} \\
\hline University of Oulu & & \\
\hline University of Tampere & & \\
\hline \multicolumn{3}{|l|}{ University of Turku } \\
\hline \multicolumn{3}{|l|}{ University of Vaasa } \\
\hline \multicolumn{3}{|l|}{$\begin{array}{l}\text { Lappeenranta Univ. of } \\
\text { Technology }\end{array}$} \\
\hline \multicolumn{3}{|l|}{ Tampere Univ. of Technology } \\
\hline $\begin{array}{l}\text { Former Helsinki School of } \\
\text { Economics* of Aalto University }\end{array}$ & $\begin{array}{l}\text { Swedish School of Social } \\
\text { Science* of the University of } \\
\text { Helsinki }\end{array}$ & \\
\hline
\end{tabular}

Asterisks (*) indicate the existence of separate units with special language regulations; italics identifies specialised universities; shaded: universities situated in Helsinki.

Appendix 4.2 Language policies at Finnish universities

\begin{tabular}{|c|c|c|c|c|c|c|}
\hline & $\begin{array}{l}\text { Number of } \\
\text { participants } \\
\text { in working } \\
\text { group }\end{array}$ & $\begin{array}{l}\text { Lang } \\
. / \mathrm{LC}\end{array}$ & Nat./Tech. & Admin & Stud. & Other \\
\hline \multicolumn{7}{|c|}{ Results of the first study (January 2012) } \\
\hline \multirow[t]{2}{*}{$\begin{array}{l}\text { University of Jyväskylä } \\
2004\end{array}$} & $\begin{array}{l}14 \text { \& smaller } \\
\text { 'core group' }\end{array}$ & $\mathrm{X}$ & $\mathrm{x}$ & $\mathrm{x}$ & $\mathrm{x}$ & $\begin{array}{l}\text { Cultural } \\
\text { politics, Bus. }\end{array}$ \\
\hline & 12 & $\mathrm{x}$ & - & $\mathrm{x}$ & $\mathrm{x}$ & Bus. \\
\hline $\begin{array}{l}\text { Hanken School of } \\
\text { Economics }\end{array}$ & 11 & $\mathrm{x}$ & $\begin{array}{l}\text { Not } \\
\text { applicable }\end{array}$ & $\mathrm{x}$ & $\mathrm{x}$ & 4 dept. \\
\hline University of Helsinki & 8 & $\mathrm{X}$ & $\mathrm{x}$ & $\mathrm{X}$ & $\mathrm{X}$ & Soc Sci. \\
\hline Åbo Academy & 8 & $\mathrm{x}$ & $\mathrm{x}$ & - & $\mathrm{x}$ & All fac. \\
\hline University of Vaasa & 9 & $\mathrm{X}$ & - & $\mathrm{x}$ & $\mathrm{X}$ & Bus. \\
\hline Aalto University & $2-4$ & $\mathrm{x}$ & - & $\mathrm{X}$ & - & - \\
\hline \multirow{2}{*}{$\begin{array}{l}\text { University of Eastern } \\
\text { Finland } \\
\text { (University of Joensuu) }\end{array}$} & 8 & $\mathrm{X}$ & $\mathrm{x}$ & $\mathrm{x}$ & $\mathrm{X}$ & $\begin{array}{l}\text { Theol., Bus., } \\
\text { Comp. Sci. }\end{array}$ \\
\hline & 11 & $\mathrm{X}$ & $\mathrm{X}$ & $\mathrm{X}$ & $\mathrm{X}$ & $\begin{array}{l}\text { Soc. Sci., } \\
\text { Bus., } \\
\text { Philosophy }\end{array}$ \\
\hline $\begin{array}{l}\text { Theatre Academy (merged } \\
\text { with Sibelius Academy \& } \\
\text { Academy of Fine Arts to the } \\
\text { Arts University in 2013) }\end{array}$ & $11-12$ & - & $\begin{array}{l}\text { Not } \\
\text { applicable }\end{array}$ & $x$ & $x$ & - \\
\hline
\end{tabular}




\begin{tabular}{|l|l|l|l|l|l|l|}
\hline University of Turku & 10 & $\mathrm{x}$ & $\mathrm{x}$ & $\mathrm{x}$ & $\mathrm{x}$ & All fac. \\
\hline $\begin{array}{l}\text { Tampere University of } \\
\text { Technology }\end{array}$ & 9 & $\mathrm{x}$ & $\mathrm{x}$ & $\mathrm{x}$ & $\mathrm{x}$ & - \\
\hline University of Tampere & 5 & $\mathrm{x}$ & - & $\mathrm{x}$ & - & - \\
\hline
\end{tabular}

Abbreviations: Lang. = Languages, LC = Language Centre, Nat./Tech. = Natural/Technical sciences, Admin. = Administration, Stud. $=$ Student union/Student, Bus. = Business, Soc. Sci. = Social sciences, All fac. = All faculties, Theol. $=$ Theology, Comp. Sci. $=$ Computer sciences 
${ }^{1}$ The Centre for Applied Language Studies (Soveltavan kielentutkimuksen keskus) at the University of Jyväskylä/Finland

${ }^{2}$ In November 2013, the Solicitor General decided in favour of the student and obliged the Aalto University to define (for example in its degree regulations) the degree to which English can be used instead or in addition to Finnish and the degree to which students may use Finnish in their exams, written assignments or lectures. 